\title{
Technical Basis Document for Natural Event Hazards
}

\author{
L.J. Kripps \\ CH2M HILL Hanford Group, Inc.
}

Richland, WA 99352

U.S. Department of Energy Contract DE-AC27-99RL14047

$\begin{array}{lll}\text { EDT/ECN: } 723855 \mathrm{RO} & \text { UC: N/A } \\ \text { Cost Center: } 7 \mathrm{G} 500 & & \text { Charge Code: } 501028 \\ \text { B\&R Code: } & \text { N/A } & \text { Total Pages: } 33\end{array}$

Key Words: Natural Events, Natural Phenomena, Seismic, High Winds

Abstract: This report documents the technical basis for assigning risk bins for the Natural Event Hazards Representative Accident and associated represented hazardous conditions.

TRADEMARK DISCLAIMER. Reference herein to any specific commercial product, process, or service by trade name, trademark, manufacturer, or otherwise, does not necessarily constitute or imply its endorsement, recommendation, or favoring by the United States Government or any agency thereof or its contractors or subcontractors.

Printed in the United States of America. To obtain copies of this document, contact: Document Control Services, P.O. Box 950, Mailstop H6-08, Richland WA 99352, Phone (509) 372-2420; Fax (509) 376-4989.

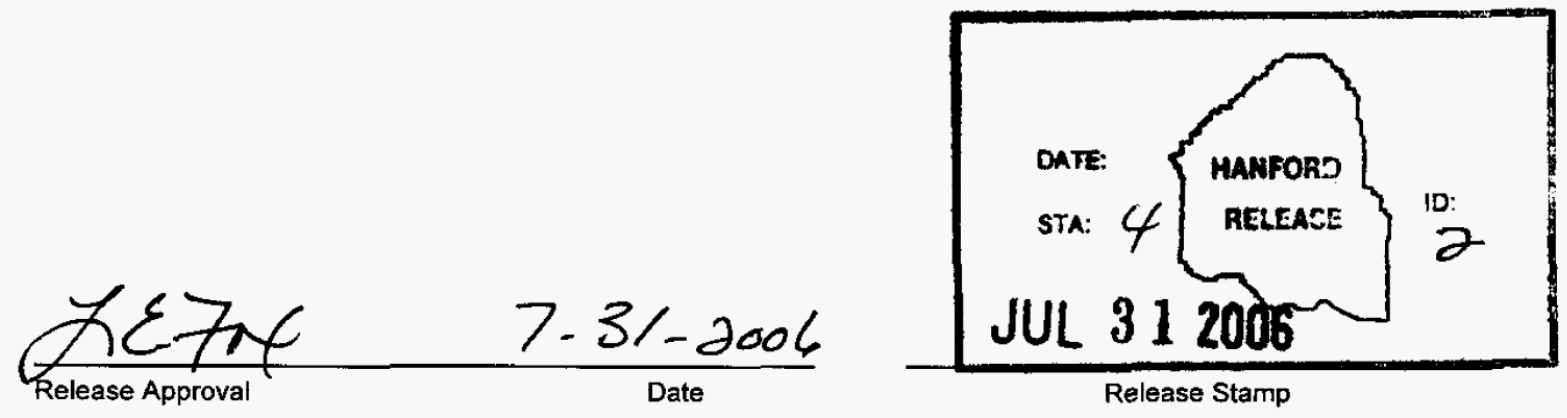

\section{Approved For Public Release}




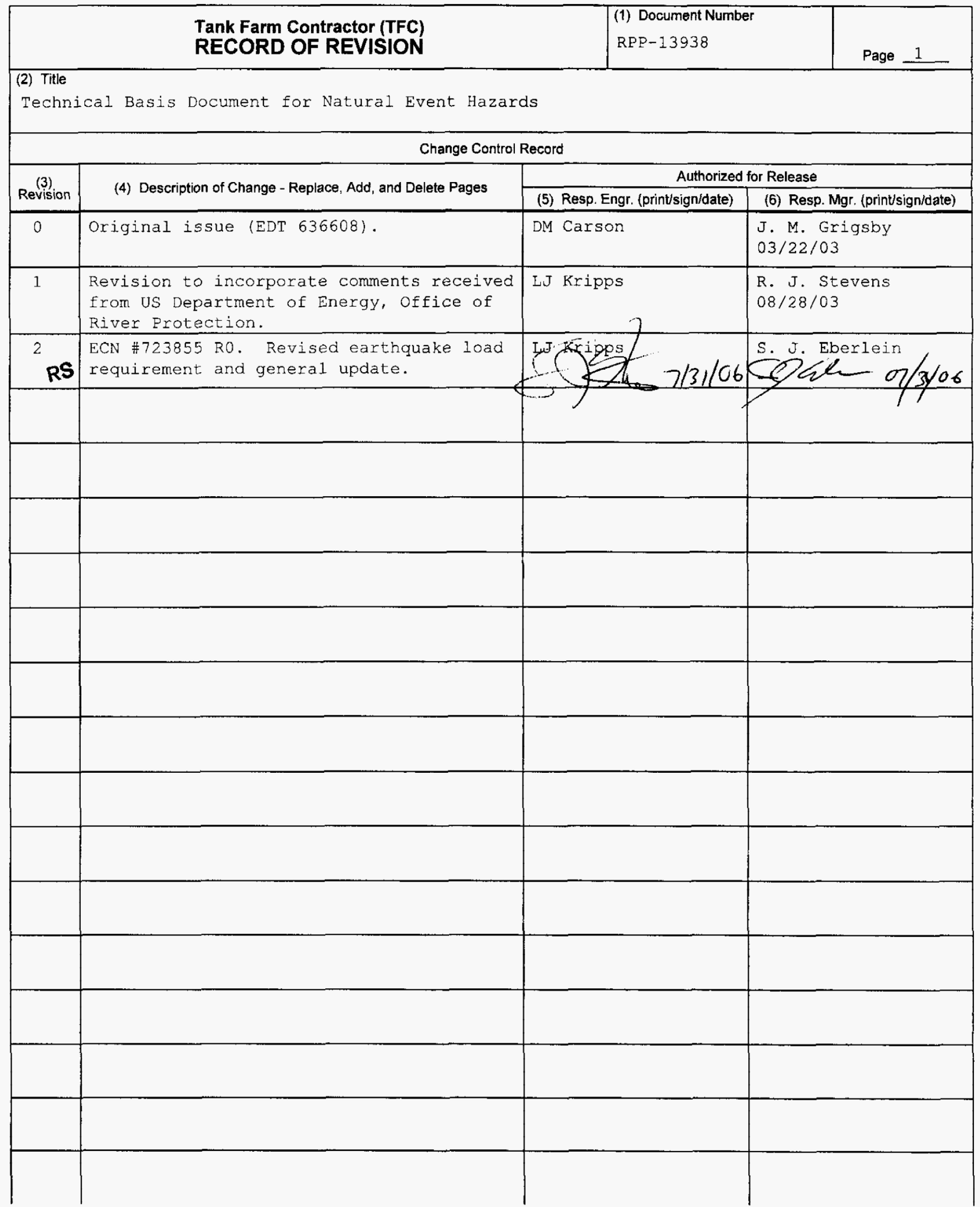

Tank Farm Contractor (TFC)
RECORD OF REVISION

(1) Document Number

(2) Title

Change Control Record

(5) Resp. Engr. (print/sign/date)

gr. (prinusign/date)

J. M. Grigsby

R. J. Stevens

$08 / 28 / 03$

LJ Kripps

$2 / 31 / 06$

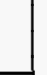




\section{CONTENTS}

$1.0 \quad$ INTRODUCTION

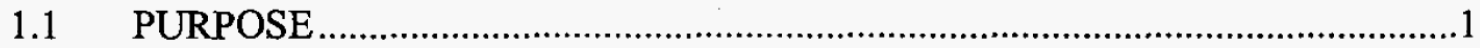

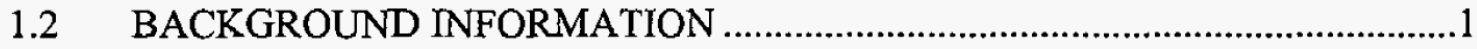

1.2.1 Representative Accidents ........................................................................1

1.2.2 Bounding Offsite Accidents.................................................................

1.2.3 Associated Hazardous Conditions .............................................................4

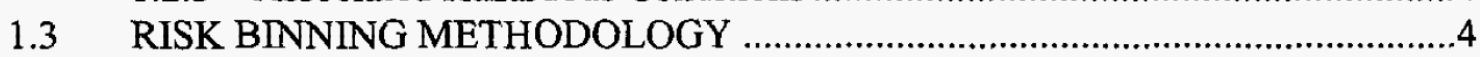

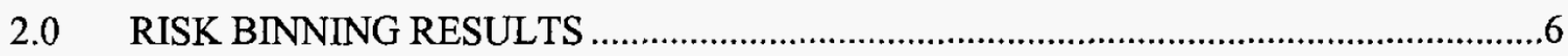

$2.1 \quad$ NATURAL EVENT HAZARD FREQUENCIES ..................................................

2.1.1 Lightning............................................................................................6

2.1.2 High Winds .....................................................................................

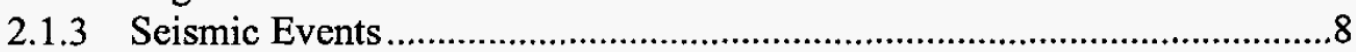

2.1.4 Extreme Temperatures ...................................................................

2.1.5 Volcanic Ashfall ..............................................................................

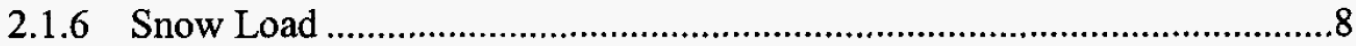

2.2 CONSEQUENCE DETERMINATION ………................................................

2.2.1 Assignment of Consequence Levels for the Onsite Receptors ....................9

2.3 NATURAL EVENT REPRESENTED HAZARDOUS CONDITIONS ................9

3.0 CONTROL SELECTION

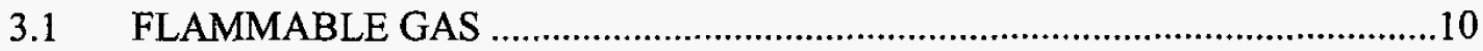

3.2 TANK FAILURE DUE TO EXCESSIVE LOADS ...........................................11

3.3 WASTE TRANSFER LEAK ……………………........................................11

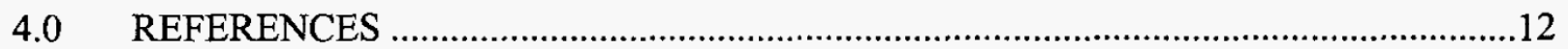

\section{APPENDICES}

A. NATURAL EVENT RISK BINNING MEETING ATTENDEES …………............... A-i

B. NATURAL EVENT CONTROL DECISION MEETING ATTENDEES ........................ B-i

C. CHECKLIST FOR TECHNICAL PEER REVIEW ……………............................... C-i 
RPP-13938 REV 2

\section{LIST OF TABLES}

Table 1. Representative Accident/Natural Event Hazards Initiator Matrix.................................. 2

Table 2. Offsite (Toxicological Only) Risk Bins....................................................................... 5

Table 3. Onsite $(100 \mathrm{~m})$ Risk Bins......................................................................................... 5

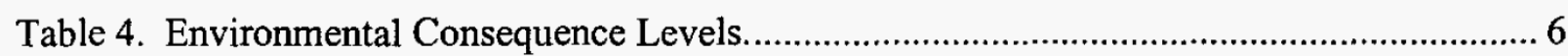

Table 5. Summary of Results for Representative Accidents for Natural Event Hazards-Initiated Accidents (Without Controls)....................................................... 7 


\section{LIST OF TERMS}

A

DSA

DST

ERPG

$\mathrm{H}$

$\mathrm{L}$

LCO

LFL

$\mathrm{M}$

MOI

$\mathrm{NEH}$

ORP

PC

SSC

SST

TEEL

TSR

TWG

$\mathrm{U}$ anticipated

documented safety analysis

double-shell tank

emergency response planning guideline

high

low

limiting condition for operation

lower flammability limit

moderate

maximally-exposed offsite individual

natural event hazards

Office of River Protection

performance category

structures, systems, and components

single-shell tank

Temporary Emergency Exposure Limit technical safety requirement

Technical Working Group

unlikely 
Page 9 of 36 of DA03128267

\section{RPP-13938 REV 2}

This page intentionally left blank. 


\section{RPP-13938 REV 2}

\subsection{INTRODUCTION}

\subsection{PURPOSE}

This technical basis document was developed to support the documented safety analysis (DSA) and describes the risk binning process and the technical basis for assigning risk bins for natural event hazard (NEH)-initiated accidents. The purpose of the risk binning process is to determine the need for safety-significant structures, systems, and components (SSC) and technical safety requirement (TSR)-level controls for a given representative accident or represented hazardous conditions based on an evaluation of the frequency and consequence. Note that the risk binning process is not applied to facility workers, because all facility worker hazardous conditions are considered for safety-significant SSCs and/or TSR-level controls (see RPP-14286, Facility Worker Technical Basis Document). Determination of the need for safety-class SSCs was performed in accordance with DOE-STD-3009-94, Preparation Guide for U.S. Department of Energy Nonreactor Nuclear Facility Documented Safety Analyses, as described below.

\subsection{BACKGROUND INFORMATION}

\subsubsection{Representative Accidents}

NEH identified in the hazard evaluation database include:

- Lightning

- High winds (including wind-generated missiles) ${ }^{1}$

- Earthquakes (seismic events)

- Flooding (natural) ${ }^{2}$

- Extreme temperatures (e.g., freezing)

- Volcanic ashfall ${ }^{3}$

- Snow loads

- Dust storms/dust devils

- Hail storms

- Range fires. ${ }^{4}$

$\mathrm{NEH}$ are initiators of hazardous conditions as identified in the hazard evaluation database. Table 1 identifies which NEH are initiators of particular representative accidents.

There are no specific representative accidents for $\mathrm{NEH}$.

\footnotetext{
${ }^{1}$ Tornados are beyond design basis accidents for the Hanford Site.

${ }^{2}$ Columbia River flooding in the Hanford 200 Areas is a beyond design basis event.

${ }^{3}$ Volcanic eruption (i.e., flow of molten lava) is a beyond design basis event for the Hanford Site.

${ }^{4}$ Range fires will be identified as an "external event" in the DSA.
} 
Table 1. Representative Accident/Natural Event Hazards Initiator Matrix.

\begin{tabular}{|c|c|c|c|c|c|c|c|c|c|}
\hline Natural phenomenon initiator & \multirow{2}{*}{ 最 } & \multirow{2}{*}{ 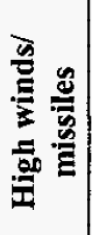 } & \multirow{2}{*}{ 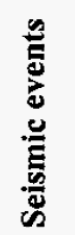 } & \multirow{2}{*}{ 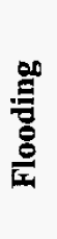 } & \multirow{2}{*}{ 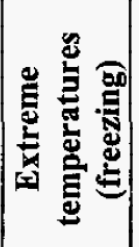 } & \multirow{2}{*}{ 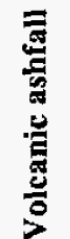 } & \multirow{2}{*}{ 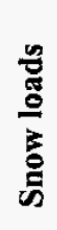 } & \multirow{2}{*}{ 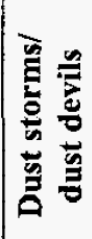 } & \multirow{2}{*}{ 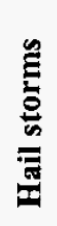 } \\
\hline Representative accident & & & & & & & & & \\
\hline Flammable gas & $\mathrm{x}$ & & $\mathrm{X}$ & & & & & & \\
\hline Release from contaminated facility & $\mathrm{x}$ & $\mathrm{x}$ & $\mathrm{x}$ & & & & & & \\
\hline Tank failure due to excessive loads & & $\mathrm{x}$ & $\mathrm{x}$ & $\mathrm{x}$ & & $\mathrm{x}$ & $\mathrm{X}$ & & \\
\hline Aboveground structure failure & & $\mathrm{x}$ & $\mathrm{x}$ & & & $\mathrm{x}$ & $\mathrm{x}$ & & \\
\hline Waste transfer leak & & $\mathrm{x}$ & $\mathrm{x}$ & & $\mathrm{x}$ & & & & \\
\hline Unplanned excavation/drilling & & $\mathrm{X}$ & $\mathrm{x}$ & $\mathrm{x}$ & & & & & \\
\hline
\end{tabular}

\subsubsection{Bounding Offsite Accidents}

Offsite radiological consequences for all accidents initiated by natural events are bounded by the calculated consequences for the following representative accidents:

- Flammable gas

- Tank failure due to excessive loads

- Waste transfer leak.

Calculations performed for these three representative accidents show that the offsite radiological consequences are $<1$ rem for tank failures due to excessive loads and waste transfer leaks, and 7 rem for the bounding flammable gas accident, as presented in the following documents:

- RPP-12395, Offsite Radiological Consequence Analysis for the Bounding Tank Failure Due to Excessive Loads Accident

- RPP-13470, Offsite Radiological Consequence Analysis for the Bounding Flammable Gas Accident

- RPP-14499, Offsite Radiological Consequence Analysis for the Waste Transfer Leak.

Potential failure modes of single-shell tanks (SST) and double-shell tanks (DST) induced by seismic events are described in WHC-SD-TWR-RPT-002, Structural Integrity and Potential Failure Modes of the Hanford High-Level Waste Tanks (see Section 5.6, "Beyond Design Basis Earthquakes"). The expected failure modes of SSTs and DSTs for seismic events are similar to (200-series SSTs) or bounded by (100-series SSTs and DSTs) the tank dome collapse postulated 


\section{RPP-13938 REV 2}

for tank failure due to excessive concentrated loads in RPP-12395. That is, for significant seismic events:

- 200-series SSTs - The flat roof is assumed to collapse and result in a hole on top of the tank.

- $\quad 100$-series SSTs - The failure mode of the tank structure is likely a localized area with deep cracks in the wall near the footing resulting in some failure in the liner in the same general location. Dome cracking on the inner and outer face would occur, but no continuous, large, through-the-thickness cracking is expected. Some spalling may occur on the inner wall.

- DSTs - The failure mode would be localized. Cracks would develop in the dome, wall, and footing. The primary tank would remain intact at the dome. No open crack failure is predicted in the dome. Possible leak at weld cracks of primary tank at the bottom and corners.

The DELPHI expert panel also evaluated the tank structure of SSTs and DSTs for seismic loads and their findings are similar to the above (WHC-SD-TWR-RPT-003, DELPHI Expert Panel Evaluation of Hanford High Level Waste Tank Failure Modes and Release Quantities). See also RPP-RPT-26718, Dome Load Collapse Assessment for Hanford Double- and Single-Shell Tanks.

The only unique aspect of natural events is the potential of NEH to cause multiple (i.e., common cause) failures. The natural event postulated to result in the highest consequences is a design (evaluation) basis earthquake that causes the uncontrolled releases of radioactive and other hazardous material from multiple accidents, which could include flammable gas accidents, tank failures due to seismic loads, and waste transfer leaks. The bounding unmitigated analysis of a design basis earthquake concluded that the potential offsite radiological consequences would not challenge the 25 rem Evaluation Guideline (DOE-STD-3009-94, Appendix A), and, therefore, no safety-class SSCs are required to protect the offsite public from the radiological consequences of natural events. The bases for this conclusion, which are also applicable for the evaluation of onsite radiological and offsite and onsite toxicological consequences, are:

- Although a natural event (e.g., design basis earthquake or high wind) may cause multiple accidents (e.g., flammable gas accidents, tank failures), it is not reasonable to expect that all of the releases would be the highest estimated release for the individual accidents. That is, there would be a range of consequences below the reasonably conservative consequences estimated for each individual accident.

- The offsite and onsite radiological and toxicological exposures from the multiple accidents are not additive because the accidents occur at different locations within the tank farms. That is, a hypothetical maximally-exposed offsite individual (MOI) at the Hanford Site boundary and a hypothetical onsite worker at $100 \mathrm{~m}$ will not receive the maximum exposure estimated from every release location.

For these reasons, the risk binning team also judged that even if natural events initiated multiple accidents, any cumulative effect would not increase the consequence level (see Section 1.3) for 
the MOI (toxicological) or onsite worker $(100 \mathrm{~m})$ (radiological and toxicological) and, therefore, no additional controls (safety SSCs and TSRs) are required.

\subsubsection{Associated Hazardous Conditions}

Potential hazardous conditions initiated by $\mathrm{NEH}$ are included under other representative accidents.

\subsection{RISK BINNING METHODOLOGY}

Direction on risk binning was provided by the U.S. Department of Energy, Office of River Protection (ORP) (Klein and Schepens, 2003, "Replacement of Previous Guidance Provided by RL and ORP"). Risk binning begins with a qualitative evaluation of the frequency and consequences of the representative accident. Frequency is qualitatively estimated as "anticipated," "unlikely," "extremely unlikely," or "beyond extremely unlikely." Consequences are evaluated for the following receptors and exposures: offsite toxicological, onsite radiological, and onsite toxicological. These consequences are assigned to one of three levels: high, moderate, or low. Based on the frequency and consequence, risk bins (ranging from I to IV) are assigned. Tables 2 and 3 show the criteria for assigning the frequency and consequence levels, and the risk bins, which are assigned to the various combinations of frequency and consequence. After the risk binning process is completed for the representative accident, the process is then repeated for the represented hazardous conditions associated with the representative accident.

In accordance with the control selection guidelines in Klein and Schepens (2003), Risk Bin I events require safety-significant SSCs or TSRs, and Risk Bin II events must consider safety-significant SSCs and TSRs. Risk Bin III events are generally protected by the safety management programs, and Risk Bin IV events do not require additional measures. Initial DSA development was largely completed before Klein and Schepens (2003) was issued and more conservative control selection guidelines were used. During the initial DSA development, safety SSCs or TSRs were required for accidents or hazardous conditions that were assigned to risk bins I or II, and were considered for accidents or hazardous conditions that were assigned to Risk Bin III. For accidents or hazardous conditions assigned to Risk Bin IV, safety SSCs and TSRs were not expected. Safety management programs were acceptable for addressing the residual risk posed by Risk Bin IV conditions. 
Table 2. Offsite (Toxicological Only) Risk Bins.

\begin{tabular}{|c|c|c|c|c|}
\hline \multirow[b]{2}{*}{$\begin{array}{l}\text { Consequence level } \\
\text { (toxicological only })\end{array}$} & \multicolumn{4}{|c|}{ Event frequency } \\
\hline & $\begin{array}{c}\leq 10^{-6} / y r \\
\text { Beyond extremely } \\
\text { unlikely }\end{array}$ & $\begin{array}{c}>10^{-6} \text { to } \leq 10^{-4} / y r \\
\text { Extremely } \\
\text { unlikely }\end{array}$ & $\begin{array}{c}>10^{-4} \text { to } \leq 10^{-2} / \mathrm{yr} \\
\text { Unlikely }\end{array}$ & $\begin{array}{c}>10^{-2} \text { to } \leq 10^{-1} / \mathrm{yr} \\
\text { Anticipated }\end{array}$ \\
\hline $\begin{array}{l}\geq \text { ERPG-2 / TEEL-2 } \\
\text { (High) }\end{array}$ & III & II & I & I \\
\hline $\begin{array}{l}\text { >ERPG-1 / TEEL-1 to } \\
\text { <ERPG-2 / TEEL-2 } \\
\text { (Moderate) }\end{array}$ & IV & III & II & I \\
\hline $\begin{array}{l}<\text { ERPG-1 / TEEL-1 } \\
(\text { Low) }\end{array}$ & IV & IV & III & III \\
\hline
\end{tabular}

Notes:

${ }^{a}$ Radiological consequences for the offsite receptor are evaluated in accordance with DOE-STD-3009-94, 2002, Preparation Guide for U.S. Department of Energy Nonreactor Nuclear Facility Documented Safety Analyses, Change Notice No. 2, Appendix A, U.S. Department of Energy, Washington D.C.

ERPG = emergency response planning guideline.

TEEL = Temporary Emergency Exposure Limit.

Table 3. Onsite (100 m) Risk Bins.

\begin{tabular}{|c|c|c|c|c|}
\hline \multirow[b]{2}{*}{$\begin{array}{l}\text { Consequence level } \\
\text { (radiological/ } \\
\text { toxicological) }\end{array}$} & \multicolumn{4}{|c|}{ Event frequency } \\
\hline & $\begin{array}{c}\leq 10^{-6} / \mathrm{yr} \\
\text { Beyond extremely } \\
\text { unlikely }\end{array}$ & $\begin{array}{c}>10^{-6} \text { to } \leq 10^{-4} / \mathrm{yr} \\
\text { Extremely } \\
\text { unlikely }\end{array}$ & $\begin{array}{c}>10^{-4} \text { to } \leq 10^{-2} / \mathrm{yr} \\
\text { Unlikely }\end{array}$ & $\begin{array}{c}>10^{-2} \text { to } \leq 10^{-1} / y r \\
\text { Anticipated }\end{array}$ \\
\hline $\begin{array}{l}\geq 100 \text { rem } \\
\geq \text { ERPG-3 / TEEL-3 } \\
\text { (High) }\end{array}$ & III & II & I & I \\
\hline $\begin{array}{l}\geq 25 \text { to }<100 \text { rem } \\
\geq \text { ERPG-2 / TEEL-2 to } \\
<\text { ERPG-3 / TEEL-3 } \\
\text { (Moderate) }\end{array}$ & IV & III & II & I \\
\hline $\begin{array}{l}<25 \text { rem } \\
<\text { ERPG-2 / TEEL-2 } \\
\text { (Low) }\end{array}$ & IV & IV & III & III \\
\hline
\end{tabular}

Notes:

ERPG = emergency response planning guideline.

TEEL = Temporary Emergency Exposure Limit. 


\section{RPP-13938 REV 2}

Environmental consequences are also assigned during the risk binning process. There are four levels of environmental consequences (E0, E1, E2, and E3, in order of increasing severity) and these levels are defined in Table 4.

Table 4. Environmental Consequence Levels.

\begin{tabular}{|c|l|}
\hline Category & \multicolumn{1}{|c|}{ Definition } \\
\hline E3 & Offsite discharge or discharge to groundwater \\
\hline E2 & Significant discharge onsite \\
\hline E1 & Localized discharge \\
\hline E0 & No significant environmental consequence \\
\hline
\end{tabular}

\subsection{RISK BINNING RESULTS}

A risk binning team meeting was conducted on October 1, 2002, to obtain consensus on the identification of $\mathrm{NEH}$ initiators of hazards and the assignment of frequencies, consequences, and risk bins. The attendees represented a wide range of expertise in the areas of engineering, licensing, and operations, and included representatives from the ORP. Appendix A lists the attendees and the organization each attendee represents. After the meeting, the risk binning results were distributed to the Technical Working Group (TWG) for review and concurrence. The risk binning results, including subsequent revisions, are shown in Table 5.

\subsection{NATURAL EVENT HAZARD FREQUENCIES}

$\mathrm{NEH}$ that can initiate a representative accident are discussed in the sections that follow except for flooding. Columbia River flooding in the 200 Areas is a beyond design basis event. The frequencies reported are those that were used in the NEH risk binning meeting to determine the frequencies of the NEH-initiated representative accidents.

\subsubsection{Lightning}

Lightning has an assigned frequency of "anticipated," based on the average Hanford lightning strike frequency of 0.16 lightning strikes $/ \mathrm{mi}^{2} / \mathrm{yr}$ (WHC-SD-WM-ES-387, Probability, Consequences, and Mitigation for Lightning Strikes to Hanford Site High-Level Waste Tanks). 


\section{RPP-13938 REV 2}

Table 5. Summary of Results for Representative Accidents for Natural Event Hazards-Initiated Accidents (Without Controls).

\begin{tabular}{|c|c|c|c|c|c|c|c|c|}
\hline \multirow[b]{2}{*}{ Postulated accident/hazardous condition } & \multirow[b]{2}{*}{ Frequency } & \multicolumn{4}{|c|}{ Consequences } & \multicolumn{3}{|c|}{ Risk bin } \\
\hline & & 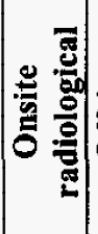 & 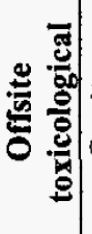 & 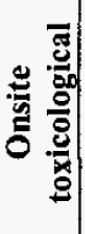 & 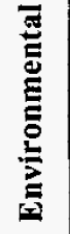 & 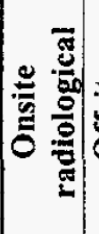 & 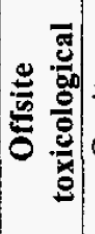 & 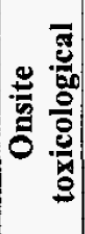 \\
\hline $\begin{array}{l}\text { Flammable gas - natural event (lightning or seismic event) } \\
\text { ignites flammable gases in } \mathrm{SST}^{\mathrm{a}}\end{array}$ & $\mathrm{U}$ & M & $\mathrm{L}$ & M & E2 & II & III & II \\
\hline $\begin{array}{l}\text { Flammable gas - natural event causes flammable gas } \\
\text { release and ignites gases in } \mathrm{SST}^{\mathrm{a}}\end{array}$ & $\mathrm{U}$ & M & $\mathbf{L}$ & M & E2 & II & III & II \\
\hline $\begin{array}{l}\text { Flammable gas - natural event fails DST active primary } \\
\text { ventilation system resulting in steady-state flammable gas } \\
\text { hazard }\end{array}$ & $\mathrm{U}$ & $\mathbf{L}$ & $\mathbf{L}$ & M & E2 & III & III & II \\
\hline $\begin{array}{l}\text { Tank failure due to excessive loads - seismic event causes } \\
\text { structural failure of an SST or DST }\end{array}$ & $\mathrm{U}$ & $\mathbf{L}$ & $\mathrm{L}$ & M & E3 & III & III & II \\
\hline $\begin{array}{l}\text { Waste transfer leak - seismic event causes fine spray } \\
\text { waste leak }\end{array}$ & $\mathbf{U}$ & M & $\mathrm{L}$ & $\mathbf{H}$ & E1 & II & III & I \\
\hline Waste transfer leak - freezing causes large pipe break & A & $\mathrm{H}$ & $\mathrm{L}$ & $\mathrm{H}$ & $\mathrm{E} 2$ & I & III & I \\
\hline 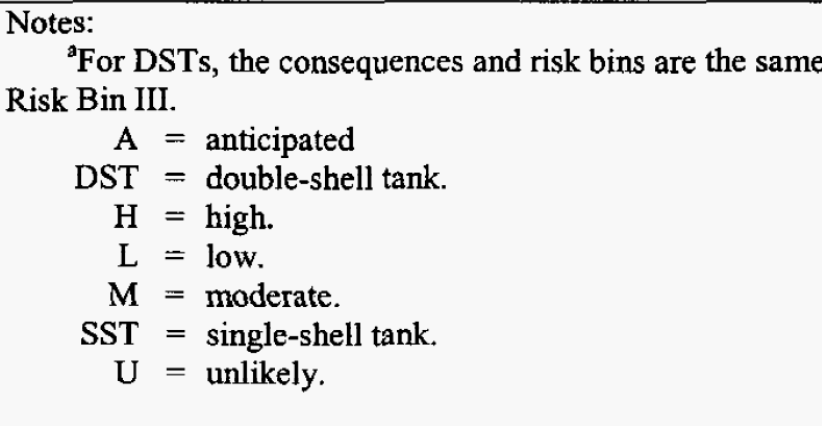 & except for ons & ite radi & iologic & al whi & ch ar & "low" & " and & \\
\hline
\end{tabular}

\subsubsection{High Winds}

High winds have assigned frequencies of "anticipated" for winds high enough to cause some accidents such as a crane dropping its load or tearing a flex receiver bag, and "unlikely" for the design-basis performance category (PC)-2 event (DOE-STD-1020-2002, Natural Phenomena Hazards Design and Evaluation Criteria for Department of Energy Facilities) that could cause structural failures (e.g., 242-T Evaporator Building failure).

The "unlikely" wind is similar to a PC-2-level event, and is based on the annual probability of exceedance, $10^{-2}$; the "three-second gust" wind velocity is $91 \mathrm{mi} / \mathrm{h}$ (DOE-STD-1020-2002). There are no wind-generated missile criteria for PC-2. 


\subsubsection{Seismic Events}

Seismic events have assigned frequencies of "anticipated" for an event large enough to create an ignition source or to cause some accidents such as a crane dropping its load, and "unlikely" for the design basis PC-2 event (DOE-STD-1020-2002) that could cause structural failures (e.g., SST/DST dome collapse).

The "unlikely" seismic event is similar to a PC-2 event. The earthquake load requirement for PC-2 is to follow International Building Code Seismic Use Group III - 2/3 Maximum Considered Earthquake ground motion with an Importance Factor of 1.5. Based on the 2,500 year return period for the maximum considered earthquake, the frequency of seismically-induced accidents is "unlikely."

\subsubsection{Extreme Temperatures}

Extreme temperatures (e.g., freezing) have an assigned frequency of "anticipated" because they have occurred and will most likely continue to occur at Hanford.

\subsubsection{Volcanic Ashfall}

Volcanic ashfall has an assigned frequency of "unlikely" for the design basis PC-2 event.

The "unlikely" volcanic ashfall is similar to a PC-2 event and is based on the annual probability of exceedance, $10^{-3}$; the design basis ashfall loading is $5 \mathrm{lb} / \mathrm{ft}^{2}$ (WHC-SD-GN-ER-30038, Volcano Ashfall Loads for the Hanford Site).

\subsubsection{Snow Load}

Snow loading has an assigned frequency of "unlikely." The design basis snow loading is $15 \mathrm{lb} / \mathrm{ft}^{2}$ (TFC-ENG-STD-06, Design Loads for Tank Farm Facilities). 
RPP-13938 REV 2

\subsection{CONSEQUENCE DETERMINATION}

\subsubsection{Assignment of Consequence Levels for the Onsite Receptors}

Consequence levels in Table 5 for representative accidents for the NEH-initiated accidents are assigned in the applicable representative accident technical basis documents:

- RPP-12444, Technical Basis for the Tank Failure Due to Excessive Loads Representative Accident and Associated Represented Hazardous Conditions

- RPP-13510, Flammable Gas Technical Basis Document

- RPP-13750, Waste Transfer Leaks Technical Basis Document.

\subsection{NATURAL EVENT REPRESENTED HAZARDOUS CONDITIONS}

Potential hazardous conditions initiated by NEH are included under other representative accidents.

\subsection{CONTROL SELECTION}

A control decision meeting was held on October 10,2002, to obtain consensus on the identification of controls for those NEH-initiated events that result in accidents assigned (without controls) to risk bins I or II. The attendees represented a wide range of expertise in the areas of engineering, licensing, and operations, and included representatives from the ORP. Appendix B lists the attendees and the organization each attendee represents. After the meeting, the results were distributed to the TWG for review and concurrence. The TWG concurred with the final control decision meeting results. In addition, all facility worker hazardous conditions, including those assigned to risk bins III or IV, were evaluated for controls as documented in RPP-14286.

For each of the representative accidents considered in this control decision meeting, various controls and SSCs were previously selected for the hazardous conditions associated with those accidents. When considering controls for NEH-initiated accidents, the control decision meeting attendees evaluated if the controls and SSCs previously selected for the individual accidents need to be protected from NEH. The control decision meeting discussions regarding the accidents under consideration, and the selected controls for those accidents are summarized in the sections that follow. Table 5 identified the frequencies, consequence levels, and risk binning for the $\mathrm{NEH}$-initiated representative accidents under consideration. 
RPP-13938 REV 2

\subsection{FLAMMABLE GAS}

There are three flammable gas scenarios considered, as presented in Table 5.

The first scenario assumes that gases are above the lower flammability limit (LFL), without controls, and a deflagration is initiated by lightning or a seismic event. The possible controls considered were flammable gas controls applicable to steady-state and gas release events (see RPP-13510). After discussion of possible operational impacts of applying the flammable gas controls, the control decision meeting participants selected these flammable gas controls as the control for this hazard.

For the seismic-induced gas release event/spark flammable gas accident, the possible controls considered included:

- Emergency preparedness program

- Tank inventory

- Seismic qualifications.

After discussions relating to the amounts of possible gas releases in SSTs versus DSTs, and if any control could be considered effective or even credible, the control decision meeting participants selected the emergency preparedness program as the control for this hazard. That is, the emergency preparedness program will have seismic response procedures that include evacuation of the tank farms to mitigate the consequences of postulated seismically-induced flammable gas accidents.

For the seismic-induced steady-state flammable gas hazard, the possible controls considered included:

- Limiting condition for operation (LCO) on DST ventilation systems

- Emergency preparedness program

- Seismic qualification of DST ventilation systems.

After discussions of the true effect of barometric breathing in DSTs, the times to LFL given no ventilation or only barometric breathing, and the true frequency of this event, the control decision meeting participants selected the following as controls for this event:

- An LCO on the DST ventilation systems, involving a surveillance requirement on flammable gas concentration in DSTs without a functioning primary ventilation system

- Emergency preparedness program.

Seismic qualification of DST ventilation systems was not selected as a control since this requirement is not necessary to meet the DST primary ventilation system safety function to maintain the concentration of flammable gases from steady-state releases below the LFL in the DST headspace. That is, the DST primary ventilation system is not required to be operating during or immediately after a significant seismic event. Based on estimates of flammable gas generation rates and accumulation in the headspace of DSTs, the minimum time required to the LFL in the DST headspace is more than one month conservatively assuming no ventilation 
RPP-13938 REV 2

(RPP-5926, Steady-State Flammable Gas Release Rate Calculation and Lower Flammability Level Evaluation for Hanford Tank Waste).

\subsection{TANK FAILURE DUE TO EXCESSIVE LOADS}

There is one tank failure due to excessive loads scenario, a seismic-initiated dome collapse, that was considered at the control decision meeting (see Table 5)

Controls considered for the seismic-initiated dome collapse accident include:

- Designation of tanks as safety-significant SSCs (with associated seismic qualification)

- Emergency preparedness program

- Dome loading controls.

After discussions regarding the seismic qualification of the tanks and if that qualification could be credited as a preventive control, the control decision meeting attendees selected only the emergency preparedness program as a control (mitigative) for this accident. That is, the emergency preparedness program will have seismic response procedures that include evacuation of the tank farms to mitigate the consequences of postulated tank failures due to seismic loads.

There was considerable discussion regarding this decision because seismic qualification is included as part of the intrinsic tank structural integrity required by the designation of the SSTs and DSTs as design features in HNF-SD-WM-SAR-067, Tank Farms Final Safety Analysis Report. A member thought that it was inappropriate to drop the currently in-place seismic qualification control (a preventive control) in favor of only a mitigative control. It was suggested that this decision is inconsistent with the control selection hierarchy established for the control decision process that places preventive controls ahead of mitigative, and engineered features ahead of administrative controls. Also, retaining the seismic qualification of the underground tanks would seem to be a prudent measure, which could be accomplished by designating the seismic qualification of the tanks as a passive design feature protected by the configuration management process. It was decided that the potential cost of designating the tanks safety-significant (due to the costs required to perform the rigorous certification required, as well as the costs of implementing and maintaining the safety-significant "label") provide no significant increase in safety nor any significant reduction in risks by such a designation.

\subsection{WASTE TRANSFER LEAK}

There are two waste transfer leak scenarios considered for controls as presented in Table 5: a seismic event-initiated (fine spray) waste transfer leak, and a freezing-initiated (large pipe) waste transfer leak. 
For the seismic event-initiated (fine spray) waste transfer leak, the potential controls considered include:

- Emergency preparedness program

- Seismically qualified waste transfer leak controls

- Seismic detection and interlock for automatic pump shutdown.

Cost-benefit ratios of seismically qualifying cover blocks, the times required for tank farm operations personnel to obtain information about a seismic event after one occurs, and what actions personnel took after the last seismic event were considered. Based on this discussion, the control decision meeting participants selected the emergency preparedness plan as the control for this event. As with other seismic scenarios, it was judged to be too difficult and costly to seismically qualify the amounts of equipment that would be required in the field to implement the other possible controls. Therefore, the emergency preparedness program will have seismic response procedures that include termination of waste transfers to mitigate the consequences of potential waste transfer leak accidents.

For the freezing-initiated (large pipe) waste transfer leak accident, the potential controls considered include:

- Waste transfer leak controls

- Freeze protection systems / programs.

After discussion of heat tracing systems, the control decision meeting participants selected the current suite of waste transfer leak controls as controls for this event.

\subsection{REFERENCES}

DOE-STD-1020-2002, 2002, Natural Phenomena Hazards Design and Evaluation Criteria for Department of Energy Facilities, U.S. Department of Energy, Washington, D.C.

DOE-STD-3009-94, 2002, Preparation Guide for U.S. Department of Energy Nonreactor Nuclear Facility Documented Safety Analyses, Change Notice No. 2, U.S. Department of Energy, Washington, D.C.

HNF-SD-WM-SAR-067, 2003, Tank Farms Final Safety Analysis Report, Rev. 3-L, CH2M HILL Hanford Group, Inc., Richland, Washington.

Klein, K. A. and Schepens, R. J., 2003, "Replacement of Previous Guidance Provided by RL and ORP," (letter 03-ABD-0047 to E. K. Thomson, Fluor Hanford Inc., and E. S. Aromi, CH2M HILL Hanford Group, Inc., February 4), U.S. Department of Energy, Richland, Washington. 


\section{RPP-13938 REV 2}

RPP-5926, 2005, Steady-State Flammable Gas Release Rate Calculation and Lower Flammability Level Evaluation for Hanford Tank Waste, Rev. 5, CH2M HILL Hanford Group, Inc., Richland, Washington.

RPP-12395, 2003, Offsite Radiological Consequence Analysis for the Bounding Tank Failure Due to Excessive Loads Accident, Rev. 0, CH2M HILL Hanford Group, Inc., Richland, Washington.

RPP-12444, 2004, Technical Basis for the Tank Failure Due to Excessive Loads Representative Accident and Associated Represented Hazardous Conditions, Rev. 2, CH2M HILL Hanford Group, Inc., Richland, Washington.

RPP-13470, 2005, Offsite Radiological Consequence Analysis for the Bounding Flammable Gas Accident, Rev. 2-A, CH2M HILL Hanford Group, Inc., Richland, Washington.

RPP-13510, 2006, Flammable Gas Technical Basis Document, Rev. 7, CH2M HILL Hanford Group, Inc., Richland, Washington.

RPP-13750, 2006, Waste Transfer Leaks Technical Basis Document, Rev. 17, CH2M HILL Hanford Group, Inc., Richland, Washington.

RPP-14286, 2005, Facility Worker Technical Basis Document, Rev. 2, CH2M HILL Hanford Group, Inc., Richland, Washington.

RPP-14499, 2005, Offsite Radiological Consequence Analysis for the Waste Transfer Leak, Rev. 4, CH2M HILL Hanford Group, Inc., Richland, Washington.

RPP-RPT-26718, 2006, Dome Load Collapse Assessment for Hanford Double- and Single-Shell Tanks, Rev. 0, CH2M HILL Hanford Group, Inc., Richland, Washington.

TFC-ENG-STD-06, 2006, Design Loads for Tank Farm Facilities, Rev. C, CH2M HILL Hanford Group, Inc., Richland, Washington.

WHC-SD-GN-ER-30038, 1996, Volcano Ashfall Loads for the Hanford Site, Rev. 0, Westinghouse Hanford Company, Richland, Washington.

WHC-SD-TWR-RPT-002, 1998, Structural Integrity and Potential Failure Modes of the Hanford High-Level Waste Tanks, Rev. 0A, Westinghouse Hanford Company, Richland, Washington.

WHC-SD-TWR-RPT-003, 1996, DELPHI Expert Panel Evaluation of Hanford High Level Waste Tank Failure Modes and Release Quantities, Rev. 0, Westinghouse Hanford Company, Richland, Washington.

WHC-SD-WM-ES-387, 1996, Probability, Consequences, and Mitigation for Lightning Strikes to Hanford Site High-Level Waste Tanks, Rev. 1, Westinghouse Hanford Company, Richland, Washington. 
RPP-13938 REV 2

APPENDIX A

NATURAL EVENT RISK BINNING MEETING ATTENDEES 
RPP-13938 REV 2

This page intentionally left blank.

.

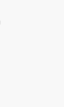

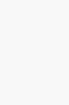

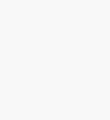

(1) 
RPP-13938 REV 2

\section{APPENDIX A}

\section{ATTENDANCE FOR NATURAL EVENT RISK BINNING MEETING,} OCTOBER 1, 2002

\begin{tabular}{|l|l|}
\hline \multicolumn{1}{|c|}{ Name } & \multicolumn{1}{c|}{ Organization } \\
\hline Craig Carro & CHG - NS\&L \\
\hline Milton Shultz & CHG - NS\&L \\
\hline Robert Carrell & ORP Support \\
\hline Thomas Mackey & CHG \\
\hline Larry Julyk & CHG \\
\hline Joseph Bevelaqua & ORP \\
\hline Lawrence J. Kripps & CHG - NS\&L \\
\hline Mark Hasty & CHG - OPS \\
\hline Harold Oak & CHG - NS\&L \\
\hline
\end{tabular}


RPP-13938 REV 2

This page intentionally left blank.

A-2 


\section{RPP-13938 REV 2}

\section{APPENDIX B}

NATURAL EVENT CONTROL DECISION MEETING ATTENDEES

B-i 
RPP-13938 REV 2

This page intentionally left blank.

B-ii 
RPP-13938 REV 2

APPENDIX B

ATTENDANCE FOR NATURAL EVENT CONTROL DECISION MEETING, OCTOBER 10, 2002

\begin{tabular}{|l|l|}
\hline \multicolumn{1}{|c|}{ Name } & \multicolumn{1}{c|}{ Organization } \\
\hline Lawrence J. Kripps & CHG - NS\&L \\
\hline Joseph Bevelaqua & ORP \\
\hline Larry Julyk & CHG \\
\hline Cliff Hampton & CHG \\
\hline Donald R. Jones & CHG \\
\hline Mark Sautman & DNFSB \\
\hline Ed Ford & CHG - NS\&L \\
\hline Craig Carro & CHG - NS\&L \\
\hline Mark Hasty & CHG - OPS \\
\hline Bob Carrell & ORP Support \\
\hline
\end{tabular}

B-1 


\section{RPP-13938 REV 2}

This page intentionally left blank.

B-2 
RPP-13938 REV 2

APPENDIX C

CHECKLIST FOR TECHNICAL PEER REVIEW

C-i 


\section{RPP-13938 REV 2}

This page intentionally left blank. 


\title{
APPENDIX C \\ CHECKLIST FOR TECHNICAL PEER REVIEW
}

\author{
CHECKLIST FOR TECHNICAL PEER REVIEW
}

Document Reviewed: RPP-13938, Rev. 2, Technical Basis Document for Natural Event Hazards

Scope of Review (e.g., document section or portion of calculation): Changes made to revision 1 that results in revision 2 .

Yes No NA*

[x] [ ] [] 1. Previous reviews are complete and cover the analysis, up to the scope of this review; with no gaps.

[x] [ ] [ ] 2. Problem is completely defined.

[x] [ ] [] 3. Accident scenarios are developed in a clear and logical manner.

[x] [] [] 4. Analytical and technical approaches and results are reasonable and appropriate. (ORP QAPP criterion 2.8)

[x] [ ] [ ] 5. Necessary assumptions are reasonable, explicitly stated, and supported. (ORP QAPP criterion 2.2)

[ ] [ ] [ $\mathrm{x}$ ] 6. Computer codes and data files are documented. (No calcs are included)

[] [] [x] 7. Data used in calculations are explicitly stated. (No calcs are included)

[] [] [x] 8. Bases for calculations, including assumptions and data, are consistent with the supported safety basis document (e.g., the Tank Farms Documented Safety Analysis). (No calcs are included)

[x] [ ] [] 9. Data were checked for consistency with original source information as applicable. (ORP QAPP criterion 2.9)

[x] [ ] [ ] 10. For both qualitative and quantitative data, uncertainties are recognized and discussed, as appropriate. (ORP QAPP criterion 2.17)

[ ] [ ] [x] 11. Mathematical derivations were checked including dimensional consistency of results. (ORP QAPP criterion 2.16) (No calcs are included

[ ] [ ] [x] 12. Models are appropriate and were used within their established range of validity or adequate justification was provided for use outside their. established range of validity. (No calcs are included

[ ] [ ] [x] 13. Spreadsheet results and all hand calculations were verified. (No calcs are included

[ ] [ ] [x] 14. Calculations are sufficiently detailed such that a technically qualified person can understand the analysis without requiring outside information. (ORP QAPP criterion 2.5) (No calcs are included

[ ] [ ] [x] 15. Software input is correct and consistent with the document reviewed. (No software is used)

[] [ ] [x] 16. Software output is consistent with the input and with the results reported in the document reviewed. (No software is used)

[ ] [ ] [x] 17. Software verification and validation are addressed adequately. (ORP QAPP criterion 2.6) (No software is used)

[x] [] [] 18. Limits/criteria/guidelines applied to the analysis results are appropriate and referenced. Limits/criteria/guidelines were checked against references. (ORP QAPP criterion 2.9)

[ ] [ ] [x] 19. Safety margins are consistent with good engineering practices.

[X] [ ] [ ] 20. Conclusions are consistent with analytical results and applicable limits.

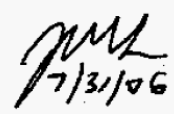




\section{RPP-13938 REV 2}

\section{CHECKLIST FOR TECHNICAL PEER REVIEW}

[x] [ ] [ ] 21. Results and conclusions address all points in the purpose. (ORP QAPP criterion 2.3)

[ ] [ ] [x] 22. All references cited in the text, figures, and tables are contained in the reference list. (See note below for all editorial question $N / A s$ )

[ ] [ ] [x] 23. Reference citations (e.g., title and number) are consistent between the text callout and the reference list.

[x] [] [] 24. Only released (i.e., not draft) references are cited. (ORP QAPP criterion 2.1)

[x] [] [x] 25. Referenced documents are retrievable or otherwise available.

[x] [ ] [x] 26. The most recent version of each reference is cited, as appropriate. (ORP QAPP criterion 2.1)

[] [] [x] 27. There are no duplicate citations in the reference list.

[] [ ] [x] 28. Referenced documents are spelled out (title and number) the first time they are cited.

[ ] [ ] [x] 29. All acronyms are spelled out the first time they are used.

[] [ ] [x] 30. The Table of Contents is correct.

[] [] [x] 31. All figure, table, and section callouts are correct.

[ ] [ ] [x] 32. Unit conversions are correct and consistent.

[ ] [ ] [x] 33. The number of significant digits is appropriate and consistent.

[] [] [x] 34. Chemical reactions are correct and balanced. (No chemical equations used)

[] [ ] [x] 35. All tables are formatted consistently and are free of blank cells.

[] [] [x] 36. The document is complete (pages, attachments, and appendices) and in the proper order.

[] [] [x] 37. The document is free of typographical errors.

[x] [ ] [] 38. The tables are internally consistent.

[x] [] [x] 39. The document was prepared in accordanice with HNF-2353, Section 4.3, Attachment B, "Calculation Note Format and Preparation Instructions".

[x] [] [ ] 40. Impacted documents are appropriately identified in Blocks 7 and 24 of the Engineering Change Notice (form A-6003-563.1).

[] [ ] [x] 41. If more than one Technical Peer Reviewer was designated for this document, an overall review of the entire document was performed after resolution of all Technical Peer Review comments and confirmed that the document is selfconsistent and complete. Note: The technical review in this peer review

[x] [ ] [ ] Concurrence checklist is in conjunction with a technical edit review by other(s).

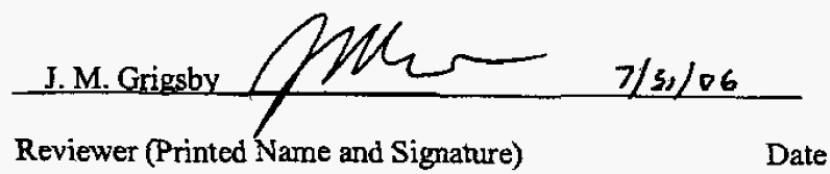

* If No or NA is chosen, provide an explanation on this form. 


\section{CHECKLIST FOR TECHNICAL PEER REVIEW}

Document Reviewed: RPP-13938, Technical Basis Document for Natural Event Hazards, Rev. 2

Scope of Review (e.g., document section or portion of calculation): Technical edit

Yes No NA*

[] [] [x] 1. Previous reviews are complete and cover the analysis, up to the scope of this review, with no gaps.

[] [] [x] 2. Problem is completely defined.

[] [] [x] 3. Accident scenarios are developed in a clear and logical manner.

[] [] [x] 4. Analytical and technical approaches and results are reasonable and appropriate. (ORP QAPP criterion 2.8)

[] [ ] [x] 5. Necessary assumptions are reasonable, explicitly stated, and supported. (ORP QAPP criterion 2.2)

[] [ ] [x] 6. Computer codes and data files are documented.

[] [ ] [x] 7. Data used in calculations are explicitly stated.

[] [] [x] 8. Bases for calculations, including assumptions and data, are consistent with the supported safety basis document (e.g., the Tank Farms Documented Safety Analysis).

[] [] [x] 9. Data were checked for consistency with original source information as applicable. (ORP QAPP criterion 2.9)

[ ] [ ] [x] 10. For both qualitative and quantitative data, uncertainties are recognized and discussed, as appropriate. (ORP QAPP criterion 2.17)

[] [ ] [x] 11. Mathematical derivations were checked including dimensional consistency of results. (ORP QAPP criterion 2.16)

[] [] [x] 12. Models are appropriate and were used-within their established range of validity or adequate justification was provided for use outside therr established range of validity.

[] [ ] [x] 13. Spreadsheet results and all hand calculations were verified.

[] [ ] [x] 14. Calculations are sufficiently detailed such that a technically qualified person can understand the analysis without requiring outside information. (ORP QAPP criterion 2.5)

[ ] [ ] [x] 15. Software input is correct and consistent with the document reviewed.

[] [] [x] 16. Software output is consistent with the input and with the results reported in the document reviewed.

[ ] [ ] [x] 17. Software verification and validation are addressed adequately. (ORP QAPP criterion 2.6)

[] [ ] [x] 18. Limits/criteria/guidelines applied to the analysis results are appropriate and referenced, Limits/criteria/guidelines were checked against references. (ORP QAPP criterion 2.9)

[] [] [x] 19. Safety margins are consistent with good engineering practices.

[] [ ] [x] 20. Conclusions are consistent with analytical results and applicable limits.

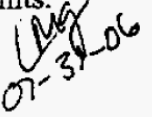




\section{RPP-13938 REV 2}

\section{CHECKLIST FOR TECHNICAL PEER REVIEW}

[ ] [ ] [x] 21. Results and conclusions address all points in the purpose. (ORP QAPP criterion 2.3)

[x] [1] [] 22. All references cited in the text, figures, and tables are contained in the reference list.

[x] [] [ ] 23. Reference citations (e.g., title and number) are consistent between the text callout and the reference list.

[x] [] [ ] 24. Only released (i.e., not draft) references are cited. (ORP QAPP criterion 2.1)

[x] [] [] 25. Referenced documents are retrievable or otherwise available.

[x] [] [ ] 26. The most recent version of each reference is cited, as appropriate. (ORP QAPP criterion 2.1)

[x] [] [] 27. There are no duplicate citations in the reference list.

[x] [] [] 28. Referenced documents are spelled out (title and number) the first time they are cited.

[x] [ ] [ ] 29. All acronyms are spelled out the first time they are used.

[x] [] [] 30. The Table of Contents is correct.

[x] [] [] 31. All figure, table, and section callouts are correct.

[x] [] [1 32. Unit conversions are correct and consistent.

[x] [] [] 33. The number of significant digits is appropriate and consistent.

[] [ ] [ $\mathrm{x}$ ] 34. Chemical reactions are correct and balanced.

[x] [ ] [] 35. All tables are formatted consistently and are free of blank cells.

[x] [] [] 36. The document is complete (pages, attachments, and appendices) and in the proper order.

[x] [] [ ] 37. The document is free of typographical errors.

[x] [] [] 38. The tables are internally consistent.

[x] [] [] 39. The document was prepared in accordance with HNF-2353, Section 4.3, Attachment B, "Calculation Note Format and Preparation Instructions".

[] [] [x] 40. Impacted documents are appropriately identified in Blocks 7 and 24 of the Engineering Change Notice (form A-6003-563.1).

[x] [] [ ] 41. If more than one Technical Peer Reviewer was designated for this document, an overall review of the entire document was performed after resolution of all Technical Peer Review comments and confirmed that the document is selfconsistent and complete.

\section{[x] [ ] [] Concurrence}

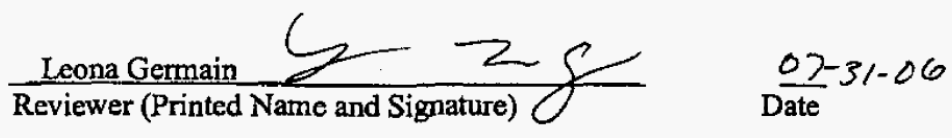

* If No or NA is chosen, provide an explanation on this form.

Technical Edit 